\title{
Analisis Gaya Pengasuhan Anak pada Pasangan Keluarga Menikah Dini
}

\author{
Intan Sri Wardani ${ }^{1 凶}$, Ali Formen ${ }^{1}$, Mulawarman ${ }^{2}$ \\ Pendidikan Anak Usia Dini, Universitas Negeri Semarang, Indonesia(1) \\ Bimbingan dan Konseling, Universitas Negeri Semarang, Indonesia(2) \\ DOI: $10.31004 /$ obsesi.v6i4.2427
}

\begin{abstract}
Abstrak
Orang tua memiliki peran penting dalam mengasuh anaknya. Mereka membutuhkan pengalaman, informasi, dan perspektif tentang tahapan tumbuh kembang anak, terutama bagi pasangan muda. Penelitian ini bertujuan untuk mengetahui penerapan gaya pengasuhan oleh pasangan muda pada wilayah pedesaan dan perkotaan khususnya Desa Krasak dan Desa Cikakak Kabupaten Brebes. Penelitian menggunakan jenis kualitatif dengan metode studi kasus. Proses pengumpulan data menggunakan instrumen lembar observasi, wawancara dan dokumentasi. Penelitian ini menggunakan teknik keabsahan data berupa triangulasi pengambilan data dan triangulasi waktu. Analisisis data yang di gunakan mengacu pada analisis Miles \& Huberman tentang alur analisis kontekstual yang meliputi 3 prosedur yaitu: (1) kondensasi data (2) menampilkan data (3) menggambar dan memverifikasi kesimpulan. Hasil penelitian menunjukkan gaya pengasuhan pasangan muda baik Desa Krasak dan Desa Cikakak di lakukan secara authoritative (demokratis) yang memberikan kebutuhan anak, kehangatan, kasih sayang, dan komunikasi yang bagus. Pasangan muda juga mendapatkan dukungan dari orang tuanya dalam kegiatan pengasuhan anak.
\end{abstract}

Kata Kunci: gaya pengasuhan; pasangan muda; anak usia dini

\section{Abstract}

Parents have a crucial role in caring for their children. They require experience, information, and perspectives on the children stages of growth, especially for young couples. This study intend to determine the application of parenting styles carried out by young couples in rural and urban areas, especially Krasak Village and Cikakak Village, Brebes Regency. This research used a qualitative type with a case study method. The process of collecting data used the instrument of observation sheets, interview and documentation. This study uses data validity techniques in the form of data retrieval and time triangulation. The data analysis refers to Miles \& Huberman's analysis of the contextual analysis flow which includes 3 procedures, namely: (1) data condensation, (2) data display (3) drawing and verifying conclusions. The results showed that the parenting style of young couples both in Krasak Village and Cikakak Village is carried out in an authoritative manner that provides children's needs, warmth, affection, and good communication. Young couples also get support from their parents in parenting activities.

Keywords: parenting style; young couple; children

Copyright (c) 2022 Intan Sri Wardani, et al.

$\triangle$ Corresponding author :

Email Address : ardani589@gmail.com (Brebes, Indonesia)

Received 14 November 2021, Accepted 23 February 2022, Published 25 February 2022 


\section{PENDAHULUAN}

Lingkungan keluarga merupakan salah satu pembentuk pribadi seorang anak pertama kalinya yang akan memberikan stimulasi untuk membantu pertumbuhan dan perkembangan anak agar dapat menjadi optimal. Keluarga juga memiliki peranan terpenting yang bertanggung jawab dalam mendidik, mengasuh dan membimbing anak dengan tujuan membentuk sikap tanggung jawab, mengetahui nilai dan moral yang ada di masyarakat serta menciptakan generasi yang bermanfaat bagi diri sendiri dan juga orang lain (Zain \& Fauziddin, 2020). Menjadikan anak yang berkepribadian juga merupakan tugas dari orang tua, oleh sebab itu faktor keberhasilan pendidikan anak adalah pemberian gaya pengasuhan yang sesuai.

Gaya pengasuhan sendiri menurut Baumrind dalam Lestari (2016) terdapat empat macam bentuk yang dapat di terapkan dengan cara dan dimensi yang berbeda-beda, di antaranya yaitu gaya pengasuhan authoritarian (otoritatif), gaya pengasuhan authoritative (demokratis), gaya pengasuhan permissive (serba membolehkan), dan gaya pengasuhan penelantar (rejecting-neglecting). Berbagai tipe gaya pengasuhan tersebut tentunya akan memberikan dampak output yang berbeda-beda pada setiap anak apalagi pendidikan utama yang di dapatkan oleh seorang anak berasal dari lingkungan keluarga (Handayani et al., 2020).

Pengasuhan pada seorang anak merupakan suatu cara yang terbaik yang di tempuh oleh orang tua dalam hal mendidik karena merupakan kewajiban yang bersifat primer dan hadirnya seorang anak merupakan hasil dari buah kasih sayang, cinta kasih yang diikat dalam suatu tali pernikahan antara suami dan istri dalam suatu keluarga (Rofingah, 2020). Orang tua juga memiliki peran terpenting yang di jadikan madrasah pertama oleh anak-anaknya sehingga menjadikan satu sosok gambaran utama bagaimana akan membentuk perilaku dan karakter bagi anak, selain itu kualitas perkawinan orang juga mempengaruhi bagaimana cara berperilaku pada anak dengan bagimana hubungan antara suami dan istri (Elam et al., 2017).

Pengasuhan yang di lakukan orang tua juga di perlukan informasi dan pengalaman dalam merawat anak sehingga proses tersebut dapat menjadikan kesuksesan dalam pengasuhan. Akan tetapi, pada kenyataan yang terjadi di lapangan banyak hal yang memaksakan individu untuk melakukan pernikahan dini yang kemudian dalam suatu pernikahan tersebut lahir seorang anak dari pasangan muda dan mau tidak mau memaksakan mereka untuk belajar bagaimana cara pengasuhan bagi anak mereka.

Berdasarkan penelitian dari Finigan-Carr et al (2015) menyatakan bahwa pernikahan di usia remaja dan usia dewasa akan menemukan hubungan kualitas dan kuantitas dalam pengasuhan anak, hal tersebut di dukung oleh penelitian dari Hidayah et al (2019) menyatakan bahwa pasangan muda yang menikah dini dalam mengasuh anak tidak memiliki panduan dan tujuan yang jelas karena belum matang dalam pengembangan kurikulum untuk pengasuhan yang mengakibatkan dampak pada perilaku anak mereka.

Pasangan muda dalam proses pengasuhan anak sebagian besar juga masih bergantung kepada orang tuanya (kakek nenek) di karenakan masih banyak yang tinggal secara bersamaan sehingga secara otomatis adanya campur tangan dari kedua belah pihak dalam proses pengasuhan yang akan menyebabkan pembentukan kepribadian yang khas pada diri anak (Zakaria, 2019). Kakek dan nenek juga turut ikut serta dalam pengasuhan karena pasangan muda belum banyak yang mandiri dan juga belum banyak yang memiliki pengalaman terkait dengan pengasuhan anak (Ingersoll-Dayton et al., 2020).

Berbicara masalah pasangan muda yang menikah dini terdapat banyak faktor yang mempengaruhi yaitu adanya paksaan dari orang tua, untuk menghindari pergaulan bebas, muncul rasa keingintahuan mengenai seks, faktor lingkungan dan rendahnya tingkat pendidikan (Sari et al., 2018). Berdasarkan praktik yang terjadi di lapangan menunjukkan banyak kelompok remaja yang melakukan pernikahan dini pada umur 15-19 tahun dimana terjadi di daerah perkotaan sebanyak 5,8\%, sedangkan di pedesaan sebanyak $11,88 \%$ hal ini membuktikan bahwa perbedaan wilayah baik di perkotaan dan di pedesaan mempengaruhi jumlah angka remaja yang melakukan pernikahan dini di Indonesia namun pada dua daerah 
tersebut sama-sama memiliki kasus yang sama mengenai remaja menikah dini (Febriani et al., 2020).

Salah satu Kabupaten yang memiliki angka pernikahan dini terbanyak yaitu terjadi di Kabupaten Brebes dengan jumlah yang meningkat pada setiap tahunnya di tambah dengan situasi yang sekarang ini sedang terjadi karena adanya corona virus menyebabkan tingginya permintaan dispensasi menikah pada remaja sehingga setiap tahunnya terjadi peningkatan secara signifikan dari tahun ke tahun. Berdasarkan hasil observasi lapangan di Pengadilan Agama Kabupaten Brebes penulis mendapatkan data terkait rincian rekapitulasi yang melakukan dispensasi menikah dari 17 Kecamatan yang ada di Kabupaten Brebes. Terdapat 5 Kecamatan yang menjadi langganan penyumbang angka permintaan dispensasi menikah dini di setiap tahunnya, antara lain yaitu Banjarharjo, Ketanggungan, Larangan, Brebes dan Wanasari.

Dari uraian tersebut peneliti tertarik untuk melakukan penelitian di daerah pedesaan dan juga perkotaan untuk mengetahui perbandingan pengasuhan anak yang di lakukan oleh pasangan muda. Penelitian ini di lakukan pada daerah perkotaan yaitu di Desa Krasak Kecamatan Brebes yang dekat dengan pusat pemerintahan Kabupaten Brebes dan daerah pedesaan yaitu di Desa Cikakak Kecamatan Banjarharjo yang berada ujung sebelah barat dengan akses yang jauh dari pusat pemerintahan Kabupaten Brebes dan berbatasan langsung dengan wilayah Jawa Barat. Desa Krasak dan Desa Cikakak dipilih karena keduanya merupakan desa yang ada di 5 kecamatan tertinggi yang sudah di jabarkan sebelumnya dengan jumlah penyumbang tertinggi dari angka pernikahan dini di Kabupaten Brebes setiap tahunnya.

T dari penelitian ini yaitu untuk mengetahui gaya pengasuhan anak yang di lakukan oleh pasangan muda pada daerah perkotaan dan pedesaan di Kabupaten Brebes karena melihat setiap tahunnya daerah ini merupakan salah satu penyumbang angka pernikahan dini terbanyak. Apalagi Kabupaten Brebes menjadi salah satu yang di berikan penghargaan sebagai kota layak anak (KLA) yang seharusnya bisa menekan angka terkait pernikahan dini pada remaja. Selain itu perlunya pengkajian sejak dini bagaimana gaya pengasuhan yang di lakukan oleh orangtua muda terlebih dengan terjun langsung ke wilayah sasaran yang menjadi langganan penyumbang terbesar di Kabupaten Brebes dan melakukan pembandingan antar kedua tempat di daerah yang di tuju apakah terdapat persamaan ataupun perbedaan dalam hal pengasuhan anak.

\section{METODOLOGI}

Jenis penelitian yang di gunakan merupakan penelitian kualitatif dengan metode studi kasus dengan tujuan untuk menggali fenomena permasalahan yang terjadi (Nurdin \& Hartati, 2019). Dari fenomena tersebut sehingga dapat memahami secara kronologis, pasti, dan jelas mengenai bagaimana pasangan muda yang menikah dini dalam mengasuh anak baik di daerah perkotaan maupun pedesaan yang ada di Kabupaten Brebes. Penelitian Kualitatif adalah penelitian yang bermaksud untuk mengetahui suatu fenomena yang dialami oleh subyek penelitian dalam aktivitas keseharian berupa perilaku dalam bertindak, persepsi dalam menemui permasalahan, motivasi untuk berbuat maupun tindakan yang di lakukan (Moleong, 2017).

Lokasi penelitian yang digunakan dalam mengamati gaya pengasuhan anak pada pasangan muda di Kabupaten Brebes yaitu di 2 lokasi berbeda diantaranya Desa Krasak Kecamatan Brebes yang masuk daerah perkotaan dan Desa Cikakak Kecamatan Banjarharjo daerah pedesaan yang jauh dari pusat kota Brebes. Pengumpulan data menggunakan cara observasi bagaimana pengasuhan yang di lakukan oleh pasangan muda dalam kegiatan pengasuhan anak, serta melakukan wawancara terhadap subyek penelitian atau informan terkait yang di gunakan untuk sampel. Wawancara yang dilakukan telah melalui proses keabsahan data, yakni konsep validitas dan reabilitas, dengan menggunakan metode triangulasi. Pertama adalah triangulasi pengambilan data dengan menguji kredibilitas data 
dengan cara yang berbeda namun dengan orang yang sama. Kedua adalah triangulasi waktu dengan mengambil data lapangan diwaktu yang berbeda agar penulis dapat menganalisis dan membandingkan jawaban dari informan sebelumnya. Adapun subyek yang digunakan dalam penelitian sebanyak 14 orang terdiri dari pasangan muda, orang tua dari pasangan muda, kepala desa, tetangga terdekat dan juga ketua RT masing-masing di Desa Krasak ataupun Desa Cikakak. Berikut informasi terkait identitas informan yang di jadikan subyek dalam penelitian telah peneliti cantumkan dalam tabel 1.

Tabel. 1 Informasi Informan

\begin{tabular}{|c|c|c|c|c|c|c|}
\hline No & Informan & $\begin{array}{c}\text { Jenis } \\
\text { Kelamin }\end{array}$ & $\begin{array}{c}\text { Usia } \\
\text { Saat Menikah (Khusus } \\
\text { Pasangan Muda) }\end{array}$ & $\begin{array}{c}\text { Saat } \\
\text { Ini }\end{array}$ & Pekerjaan & Keterangan \\
\hline 1. & KF1 & Perempuan & 17 tahun & $\begin{array}{c}22 \\
\text { tahun }\end{array}$ & IRT & Ibu Muda 1 \\
\hline 2. & RM1 & Laki-laki & 20 tahun & $\begin{array}{c}25 \\
\text { tahun }\end{array}$ & Pedagang & Ayah Muda 1 \\
\hline 3. & JR2 & Perempuan & 19 tahun & $\begin{array}{c}21 \\
\text { tahun }\end{array}$ & IRT & Ibu Muda 2 \\
\hline 4. & RY1 & Laki-laki & 19 tahun & $\begin{array}{c}21 \\
\text { tahun }\end{array}$ & Pedagang & Ayah Muda 2 \\
\hline 5. & AM1 & Perempuan & & $\begin{array}{c}53 \\
\text { tahun }\end{array}$ & Pedagang & $\begin{array}{l}\text { Ibu KF1 } \\
\text { (Nenek) }\end{array}$ \\
\hline 6. & TM1 & Laki-laki & & $\begin{array}{c}55 \\
\text { tahun }\end{array}$ & Pedagang & $\begin{array}{c}\text { Ayah KF1 } \\
\text { (Kakek) }\end{array}$ \\
\hline 7. & NN2 & Perempuan & & $\begin{array}{c}28 \\
\text { tahun }\end{array}$ & IRT & Ibu Wali JR2 \\
\hline 8. & WS2 & Laki-laki & & $\begin{array}{c}60 \\
\text { tahun }\end{array}$ & Pedagang & $\begin{array}{c}\text { Ayah JR2 } \\
\text { (Kakek) }\end{array}$ \\
\hline 9. & DR1 & Laki-laki & & $\begin{array}{c}49 \\
\text { tahun }\end{array}$ & $\begin{array}{c}\text { Kepala } \\
\text { Desa }\end{array}$ & $\begin{array}{c}\text { Kepala Desa } \\
\text { KF1 }\end{array}$ \\
\hline 10. & RH2 & Laki-laki & & $\begin{array}{c}46 \\
\text { tahun }\end{array}$ & $\begin{array}{c}\text { Kepala } \\
\text { Desa }\end{array}$ & $\begin{array}{c}\text { Kepala Desa } \\
\text { JR2 }\end{array}$ \\
\hline 11. & KM1 & Perempuan & & $\begin{array}{c}50 \\
\text { tahun }\end{array}$ & Petani & Tetangga KF1 \\
\hline 12. & IY2 & Perempuan & & $\begin{array}{c}53 \\
\text { tahun }\end{array}$ & IRT & Tetangga JR2 \\
\hline 13. & SS1 & Laki-laki & & $\begin{array}{c}54 \\
\text { tahun }\end{array}$ & Petani & Ketua RT KF1 \\
\hline 14. & SH2 & Laki-laki & & $\begin{array}{c}34 \\
\text { tahun }\end{array}$ & Pedagang & Ketua RT JR2 \\
\hline
\end{tabular}

Teknik pengambilan data yang digunakan yaitu dengan 3 cara yaitu observasi, wawancara dan dokumentasi (Sugiyono 2015). Observasi dilakukan untuk mengetahui bagaimana ritme pengasuhan anak yang dilakukan oleh pasangan muda di kedua desa. Sebagai pendukung temuan dilapangan, wawancara dilakukan pasangan muda, orang tua dari pasangan muda, kepala desa, ketua RT dan juga tetangga di kedua desa tersebut. Hasil wawancara yang didapat kemudian dijabarkan melalui tulisan berupa matriks yang di sesuaikan berdasarkan pertanyaan dan jawaban tiap masing-masing informan. Sehingga dari satu informan ke informan lain dapat menemukan jawaban atas pertanyaan yang di ajukan Kemudian, dokumentasi dilakukan sebagai pelengkap penelitian dalam menjawab permasalahan yang diteliti. Analisis yang digunakan juga terdapat 3 cara menurut Miles \& Huberman (2014) diantaranya yaitu kondensasi data (data condensation), menampilkan data (data display) dan menggambar serta memverifikasi kesimpulan (conclusions: drawing/verifying). Gambar 1 adalah tahapan dalam penelitian yang di lakukan oleh peneliti. 


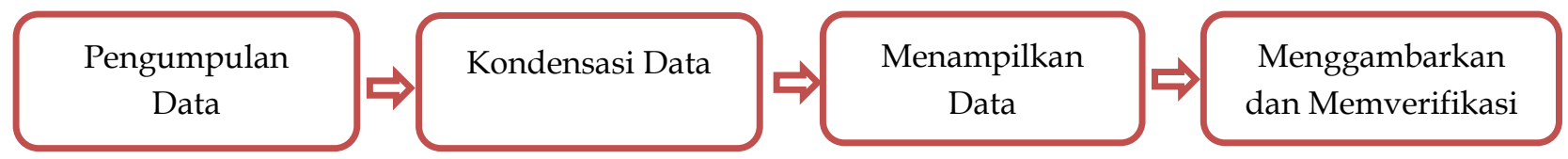

\section{Gambar 1. Tahapan Penelitian}

Kondensasi data dalam penelitian ini di lakukan dengan memilih, memfokuskan, menyederhanakan dan mengabstraksi temuan terpenting tanpa mengubah unsur utama data di lapangan pada hal-hal penting dimana memberikan data mengenai gaya pengasuhan yang di lakukan pada pasangan muda baik di daerah perkotaan maupun pedesaan yang ada di Kabupaten Brebes. Ketika sudah mendapatkan data yang lebih ringkas langkah selanjutnya yaitu dengan menampilkan data temuan untuk di analisisis lebih lanjut dalam kualitatif dengan merancang tampilan berupa uraian deskriptif, bagan maupun matriks berdasarkan data temuan terkait gaya pengasuhan anak yang di lakukan pada pasangan muda, serta langkah terakhir yang di lakukan yaitu dengan menggambarkan dan memverifikasi kesimpulan berdasarkan temuan awal hingga akhir yang di gambarkan lalu kemudian di tarik kesimpulan sehingga memperoleh suatu jawaban permasalahan terkait dengan bagaimana gaya pengasuhan yang di lakukan pada pasangan muda (Miles \& Huberman, 2014).

\section{HASIL DAN PEMBAHASAN}

Perkembangan anak dipengaruhi oleh konteks dimana ia berada, seperti latar belakang lingkungan, kultur masyarakat, maupun tempat tinggal orang tuanya (Steinberg, 1993 dalam Purwadi, 2012). Orang tua yang tinggal di perkotaan memiliki pola pengasuhan yang dipengaruhi dengan kultur modern dengan suasana kehidupan yang individualistik. Sedangkan orang tua yang tinggal di pedesaan memiliki pola asuh yang tradisional dan mementingkan kesetaraan dan kebersamaan (Purwadi, 2012). Sejalan dengan Purwadi, Wiswanti et al. (2020) juga menyampaikan bahwa orang tua yang tinggal di area perkotaan cenderung terpengaruh budaya barat dalam mengasuh anaknya, yakni menekankan kemandirian atau sifat individualisme. Sedangkan orang tua di area pedesaan pola pengasuhan menekankan pada pentingnya tata krama, kepatuhan, serta rasa hormat kepada orang tua. Berdasarkan hasil penelitian yang telah di lakukan terkait dengan gaya pengasuhan anak pada pasangan keluarga menikah dini di daerah perkotaan maupun pedesaan yang ada di Kabupaten Brebes mendapatkan beragam temuan data yang terjadi di lapangan. Remaja muda mengasuh anaknya dengan cara mereka masing-masing mengikuti kultur budaya, kebiasaan yang ada di masyakat sekitar karena keduanya tinggal di lingkungan wilayah berbeda. Remaja yang ada di Desa Krasak tinggal dengan kebiasaan adat budaya jawa, sedangkan remaja yang tinggal di Desa Cikakak menggunakan adat budaya sunda, sehingga dapat di jabarkan dalam uraian berikut.

\section{Gaya Pengasuhan Anak Pada Pasangan Menikah Dini di Daerah Perkotaan}

Gaya pengasuhan yang di lakukan oleh pasangan muda yang ada di daerah perkotaan khususnya Desa Krasak Kecamatan Brebes Kabupaten Brebes pada saat awal menikah memang belum banyak memiliki pengalaman dalam hal mengasuh anak, terlebih usia pada saat menikah masih terbilang remaja sehingga pola pikirnya belum matang namun seiring berjalannya waktu pasangan muda tersebut memiliki cerminan sikap tanggung jawab terlebih ketika hadirnya seorang anak di tengah-tengah keluarga, mereka belajar menjadi orang tua yang sebaik-baiknya untuk anak dengan memberikan pengasuhan yang terbaik.

... pasangan muda di desa krasak di lakukan, di rawat dengan baik oleh orang tuanya. Pasangan tersebut memberikan pengasuhan yang layak kepada anaknya seperti mengajaknya bermain, mengantar anaknya untuk jalan-jalan, mengantarnya rutin untuk memeriksakan ke posyandu dll (Kutipan wawancara DR1) 
Adanya tanggung jawab dari orang tua kepada anak akan menciptakan ikatan batin antara keduanya dalam hal pengasuhan dengan memperhatikan anak dan memenuhi kewajibannya sebagai orang tua sehingga menciptakan kualitas hubungan timbal balik yang baik (Aloia \& Warren, 2019). Lingkungan keluarga inti juga membentuk karakter pribadi karena madrasah pertama bagi seorang anak adalah pada orang tuanya sehingga gambaran pengasuhan orang tua adalah cikal bakal cerminan perilaku yang akan anak lakukan terutama peran seorang ibu menjadi poin utama dalam pendidikan anak (Aloia \& Warren, 2019) sejalan dengan hal tersebut penelitian dari Ceka \& Rabije (2016) menyatakan bahwa seorang anak perlu akan hadirnya seorang ibu tentunya di harapkan dapat mencapai perkembangan fisik, psikis dan sosial yang sesuai.

Pemenuhan kewajiban orang tua dalam pengasuhan anak juga memberikan cerminan bahwa hak yang di dapatkan untuk anak dapat terpenuhi sehingga tumbuh kembangnya memberikan dampak optimal bila mana di rawat dengan baik dengan cinta tulus dan kasih sayang, dari anak tersebut di lahirkan sampai dengan dewasa nantinya dimana meskipun di satu sisi orang tua dari sang anak masih berusia muda namun bertambahnya tahun mereka akan beradaptasi dengan kebiasaan tersebut sehingga terbentuk secara komrehensif dan membentuk perkembangan anak yang sesuai (Sahithya et al., 2019).

... cara mengasuh anaknya ya baik-baik saja, ya memang dia walaupun pasangan muda tapi cara mengasuh anaknya ya sudah cukup pengertian dan alhamdulillah anaknya sehat dan tidak ada kendala apa-apa dan alhamdulillah sampai sekarang juga anaknya udah gede yah alhamdulillah anaknya pinter cara mengasuh anaknya (Kutipan wawancara SS1)

Gaya pengasuhan anak merupakan suatu pola yang berkelanjutan dengan adanya interaksi antara orang tua dan juga anak untuk mengontrol bagaimana tindakan dari pada sang anak sehingga terbangun karakter dan perkembangan kelekatan emosi antara anak dan juga orang tua dengan pendekatan, pembiasaan dan juga pelayanan terbaik (Nasution et al., 2021). Berdasarkan hasil penelitian gaya pengasuhan anak yang di tetapkan pada pasangan keluarga menikah dini di daerah perkotaan khususnya Desa Krasak ini merujuk pada model authoritative (demokratis) dimana orang tua melakukan bimbingan, memberikan hak yang semestinya, penerimaan anak, ikatan kasih sayang, merawat dan mengawasi apa yang di lakukan oleh sang anak karena masih berusia balita (Mehrinejad et al., 2015).

... saya merawatnya dengan memberinya yang di butuhkan dan yang terbaik (Kutipan wawancara KF1)

... mengasuh anaknya dengan baik, me merawatnya, memberikan kebutuhan anak, mengajaknya bermain dan mengawasi mengawasi anaknya begitu (Kutipan wawancara TM1)

Penerapan gaya pengasuhan yang di lakukan orang tua muda menciptakan ikatan emosional batin antara keduanya dalam interaksi sehari-hari (Li \& Xie, 2017). Ikatan emosi ini juga sering di sebut dengan kelekatan yang di imbangi dengan komunikasi dua arah, Orang tua juga memberikan sesuai dengan kebutuhan yang di butuhkan anak sehingga dapat terpenuhi dan itu merupakan suatu bukti tanggung jawab yang tidak bisa di tinggalkan begitu saja.

Dalam hal pengasuhan anak, pasangan muda tersebut juga masih di bantu oleh orang tuanya (kakek nenek), sehingga dalam pengasuhan anak terjadi perpaduan dari kedua pihak yang menyebabkan anak akan memiliki perilaku unik (Astuti et al., 2021). Hal ini bisa terjadi karena sang suami merantau keluar kota untuk mencari nafkah bagi keluarganya di tambah dengan mereka masih tinggal satu rumah bersamaan dengan orang tua (kakek nenek)

... kebetulan saya sambil bekerja di Jakarta sehingga pengasuhan di lakukan oleh istri dan juga orang tua, tetapi ketika saya pulang saya membantu untuk mengasuh anak dengan mengajaknya bermain, jalan-jalan (Kutipan wawancara RM1) 
Meskipun dalam keadaan berjauhan dengan anak dan istrinya, sang suami juga tidak lepas akan tanggung jawabnya karena setiap saat selalu melakukan telekomunikasi dan ketika pulang juga turut serta membantu istrinya. Peran serta ayah dapat mempengaruhi pertumbuhan dan perkembangan anak secara keseluruhan pada aspek individu kehidupan dari seorang anak (Nemet \& Vrdoljak, 2021). Sejalan dengan hal tersebut Coyne et al (2017) berpendapat bahwa pengasuhan dengan menggunakan media digital sudah umum di lakukan oleh orang tua di zaman sekarang tanpa mengurangi esensi tanggung jawabnya.

Meskipun berjauhan dari sang suami, sang istri tetap menjalankan kewajibannya sebagai seorang ibu dengan cara mengasuh anak, dimana kelekatan batin dan emosional antara ibu dan anak lebih besar dari pada ke ayah karena kebanyakan seorang anak akan sering bersama sang ibu dari pada dengan ayahnya (Ardita Ceka, 2016). Pengasuhan tersebut juga turut serta melibatkan kakek nenek dalam menjaga anak karena masih tinggal di satu rumah yang sama.

\section{... yah saya ikut serta dalam me mengawasi cucu saya bermain juga dengan istri (Kutipan wawancara TM1) \\ ... yah mengasuh putu, сuсu lah, ngerumati cucu, di dulang wis lah pokoke ben sehat, endah pinter (Kutipan wawancara AM1)}

Pengasuhan kakek dan nenek juga turut serta andil dalam pelaksanaan harian dari sang cucu. Pengasuhan yang di bantu kakek dan neneknya juga memberikan dampak yang khas pada diri seorang anak karena adanya campur tangan dari kedua belah pihak khususnya karena orang terdahulu memiliki ciri khas yang kental dan di zaman yang modern ini juga turut serta belajar dalam mengikuti zaman agar sang cucu merasa aman-nyaman dan di perlakukan dengan baik, kakek nenek membantu dalam hal pengasuhan juga di ibaratkan seperti orang tua ke 2 bagi anak (Fono et al., 2019). Dari paparan yang sudah di gambarkan di atas dalam hal pengasuhan pasangan muda kepada anaknya yang di bantu oleh orang tua pasangan muda (kakek dan nenek) juga menemui beberapa kendala dalam pelaksanaannya seperti pembagian waktu, pengasuhan anak dengan posisi suami istri yang berjauhan, dan orang tua sudah berusia senja (Tridhonanto, 2014).

Gaya pengasuhan yang di terapkan oleh orang tua akan memberikan efek dan dampak bagi perjalanan perkembangan dari anak. Secara keseluruhan gaya pengasuhan yang bersifat authoritative (demokratis) akan memberikan dampak yang positif bagi anak dimana perkembangan anak akan terus bertambah seiring bergantinya tahun. Berkembangnya seorang anak juga dapat di lihat dari segi capaian aspek-aspek perkembangan seperti moral dan agama, bahasa, fisik motorik, kognitif, sosial dan emosional serta seni. Dalam mencapai aspek tersebut juga perlu adanya Kerjasama yang di lakukan antara ibu dan ayah terutama pada peran dari sang ibu (Li \& Xie, 2017)

Aspek dasar tersebut jika di kembangkan dengan baik oleh orang tua akan memberikan dampak yang baik bagi perkembangan anak karena karakteristik perkembangan anak akan berkembang dengan pesat karena masih dalam taraf golden age sehingga orang tua benar-benar harus menstimulasi dengan benar. Gaya pengasuhan authoritative (demokratis) merupakan salah satu contoh yang dapat di terapkan oleh orang tua kepada anaknya.

\section{Gaya Pengasuhan Anak Pada Pasangan Menikah Dini di Daerah Pedesaan}

Gaya pengasuhan yang di lakukan oleh pasangan muda yang ada di daerah pedesaan khususnya Desa Cikakak Kecamatan Banjarharjo Kabupaten Brebes pada saat pertama kalinya memiliki anak yaitu belum adanya kesiapan yang matang baik secara moral dan mental untuk menjadi orang tua di karenakan belum adanya pengalaman di tambah dengan usianya yang masih remaja membuat pola fikirnya belum matang dan perlu belajar dari yang sudah berpengalaman terutama orang-orang terdekat seperti orang tuanya. 
... untuk pasangan muda pada pernikahan dini itu kebanyakan masih mengandalkan ya orang tua juga karena belum siap dari awal, intinya itu masih mengandalkan malah mungkin pengalaman-pengalaman punya beban mental dasarnya itu (Kutipan wawancara RH2)

Namun pilihan untuk menikah dini di tempuh oleh pasangan muda tersebut karena faktor-faktor tertentu sehingga memaksa mereka melakukan pernikahan di usia yang masih remaja (Latifiani, 2019). Faktor menikah muda menjadi pilihan yang di ambil kebanyakan remaja khususnya di daerah terpencil karena suatu hal misalnya hamil di luar nikah, menghindari seks bebas ataupun karena pengaruh lingkunganva dan juga budaya setempat (Febriani et al., 2020).

Pengasuhan yang baik di lakukan oleh pasangan muda merupakan suatu bentuk tanggung jawab yang seharusnya di lakukan, meskipun dalam prosesnya tidak instan dan perlu waktu namun sekarang ini sudah menunjukkan bentuk kepedulian dan mulai terbiasa akan hal tersebut (Aloia \& Warren, 2019). Pasangan muda yang ada di Desa Cikakak memperoleh bagaimana cara mengasuh anaknya dari orang-orang terdekat dan sudah sadar akan kodratnya menjadi orang tua yang di panuti oleh anaknya. Karena lingkungan keluarga akan mempengaruhi bagaimana cara anak dalam bertindak kedepannya, orang tua menjadi tujuan utama bagi anak-anaknya untuk bertapak sehingga perlunya penguatan terlebih dahulu dari diri orang tua itu sendiri yang di terapkan kepada anak dengan pemberian stimulasi agar kepercayaan diri anak dapat tumbuh sebelum berbaur dengan dunia luar (Ulya et al., 2021)

Kewajiban orang tua dalam membimbing, merawat, mengasuh dan memberikan kasih sayang merupakan modal utama yang harus dimiliki dimana antara ayah dan ibu memiliki peran masing-masing dalam hal tersebut (Fono et al., 2019). Dimana di usia remaja masih asik dengan dunianya namun dengan hadirnya anak di tengah-tengah keluarga dan bertemu setiap hari membuat suasana menjadi berbeda.

... sering main tetapi setelah punya anak ya jadi di rumah terus menyadari bahwa tugas nya itu sudah tau adalah seorang ibu mengasuh anaknya (Kutipan wawancara IY2). ... untuk pengasuhan yang saya lihat baik mba sudah tau cara mengurus anak (Kutipan wawancara IY2)

Cara pengasuhan anak yang di lakukan oleh pasangan muda dengan beragam kegiatan secara berkelanjutan menyebabkan terpolanya suatu aktifitas dan menandakan gaya pengasuhan yang di gunakan dalam kegiatan sehari-hari. Di dalam gaya pengasuhan tersebut ada suatu konsep yang memiliki pola hasil bentukan dari pada orang tua. Ketika sudah terbiasa dalam mengasuh anak akan terciptanya sikap kasih sayang, penerimaan, perhatian dan hubungan keduanya menjadikan dukungan yang bersifat positif (Gouveia et al., 2016).

Berdasarkan temuan di lapangan di dapatkan bahwa gaya pengasuhan yang di lakukan oleh pasangan muda di Desa Cikakak merujuk pada authoritative (demokratis) karena orang tua memiliki tanggung jawab untuk mengawasi anak, memberikan hak anak, menjalin komunikasi baik pada anak, tidak sering memberikan hukuman pada anak (Vafaeenejad et al., 2020).

... yah mengawasi anak, mengajaknya mandi, memberinya makan, kalau ada posyandu ya kontrol ke posyandu (Kutipan wawancara JR2)

... demokratis yak, Baik lah gitu ama suaminya dan bapak (kutipan wawancara NN2) ... demokratis ya

Bagus, anaknya didik dengan baik, anaknya tidak di telantarkan ya kaya ibu ke anak ya (Kutipan wawancara SH2) 
Penerapan gaya pengasuhan tersebut membuat anak menjadi aman, nyaman, mendapatkan perhatian serta kebaikan dari orang tua yang menyebabkan perkembangan anak menjadi baik sesuai dengan usianya (Gouveia et al., 2016). Pengasuhan yang di lakukan oleh pasangan muda yang ada di Desa Cikakak juga mendapatkan dukungan pengasuhan oleh orang tuanya (kakek) serta ibu wali yang saling bekerja sama dalam mengajarkan bagaimana mengasuh anak dari sejak lahir hingga sekarang karena memang dukungan tersebut sangat di perlukan, terlebih pasangan muda yang menikah dini belum banyak pengalaman dalam proses pengasuhan kepada anak.

... yah misalkan bagi-bagi kalau sebagai kakek yah kalau ada yang nangis satu di samperin yang satunya kadang-kadang kalau lagi yang nangis satu nyamperin yang satu kaya gitu lah kirakira. Mengasuhnya ya kadang-kadang ada yang rewel ada yang engga gitu (Kutipan wawancara WS2)

Selain bantuan dalam mengasuh anak, pasangan muda juga mendapatkan bantuan dari segi lainnya yaitu berupa rumah yang di tinggali secara bersama sampai dengan finansial. ... memberikan tempat tinggal, memberikan uang jajan untuk anak, ikut menjaga anak saya, mengasuh (Kutipan wawancara JR2)

... membantu merawatnya, memberikan jajan untuk anak, di asuh bareng sama orang tua (Kutipan wawancara RY2).

Selain proses pengasuhan yang di lakukan secara berkelanjutan setiap harinya, pasangan muda juga menemukan kendala dalam proses pelaksanaannya diantaranya yaitu harus berjauhan dengan suami karena bekerja di luar kota yang menyebabkan pengasuhan melalui media telekomunikasi dan orang tua (kakek) sudah berusia senja.

Namun dari semua itu, gaya pengasuhan anak sudah di lakukan pasangan muda dengan proses yang bertahap sampai pada akhirnya dapat menerima anak dan justru merawat dengan sebaiknya tanpa adanya penelantaran dan mengabaikan hak yang seharusnya di dapatkan oleh sang anak sampai pada akhirnya pola tersebut menjadi sebuah bentuk gaya pengasuhan berupa authoritative (demokratis) sehingga memberikan kebermanfaatan dengan mengambil nilai positif yang terkandung dalam pola tersebut dan menghasilkan cerminan perilaku dari dampak yang di timbulkan.

Hasil penelitian menunjukkan bahwa tidak ada perbedaan antara gaya pengasuhan anak pada pasangan muda di perkotaan dan pedesaan. Mayoritas pasangan muda masih merasa baru dalam menjadi ibu, mereka masih minim pengalaman dan pola pikir yang masih belum matang. Hal ini sejalan dengan penelitian Purwadi (2012) yang menemukan bahwa tidak ada perbedaan pola pengasuhan di desa dan di kota, keduanya termasuk dalam kategori enabling, yaitu memberikan pengasuhan yang membangun eksplorasi dan komitmen anak. Selain itu, kedua desa menerapkan gaya pengasuhan yang demokratis. Gaya pengasuhan demokratis merupakan model pengasuhan yang sering digunakan oleh ibu-ibu muda (Irwanto et al., 2019). Anak yang diasuh dengan pola demokratis cenderung memiliki initiatif pertumbuhan diri (personal growth initiative), self-esteem, dan keahlian sosial yang lebih baik dibanding dengan pola otoritatif dan permisif atau serba membolehkan (Hirata \& Kamakura, 2018; Irwanto et al., 2019). Purwadi menambahkan bahwa terjadinya persamaan pola pengasuhan disebabkan karena latar belakang budaya yang sama. Namun, pada penelitian ini, kedua desa memiliki latar belakang budaya yang berbeda, antara budaya jawa dan budaya sunda. Tetapi, pola pengasuhannya juga masih sama.

\section{SIMPULAN}

Penelitian ini bertujuan untuk mengetahui tentang penerapan gaya pengasuhan pada pasangan muda, khususnya di wilayah Desa Krasak dan Cikakak, Kabupaten Brebes. Hasil penelitian menunjukkan bahwa kedua desa memiliki gaya pengasuhan yang hampir sama, yakni gaya pengasuhan demokratis (authoritative). Gaya pengasuhan yang di lakukan yaitu 
memberikan yang terbaik dengan melihat kebutuhan anak, merawat, mengasuh, mengajak dan menemani aktifitas harian sehingga sang anak terpenuhi akan haknya dan tidak di telantarkan oleh kedua orang tuanya, selain itu orang tua juga melakukan komunikasi dengan baik bersama sang anak dengan tidak mengekang dan tidak membebaskan anak secara berlebihan. Adapun dukungan yang di berikan oleh orang tua pada pasangan muda dalam pengasuhan di kedua desa tersebut juga cenderung sama yaitu membantu pengasuhan dan memberikan bantuan berupa papan (tempat tinggal) dan juga finansial. Sedangkan kendala yang di hadapi juga relatif sama yakni mencakup pembagian waktu, peran ayah yang jauh, dan usia orang tua yang sudah senja sehingga kurang maksimal.

\section{UCAPAN TERIMA KASIH}

Penulis mengucapkan terima kasih kepada semua pihak yang telah membantu dalam kegiatan penelitian ini. Khususnya kepada orang tua yang selalu memberikan dukungan baik secara moral maupun material, kemudian kepada informan yang telah berpartisipasi dalam penelitian ini baik dari Desa Krasak maupun Desa Cikakak Kabupaten Brebes, serta penulis ucapkan terima kasih kepada dosen PAUD UNNES yang telah memberikan bimbingan, arahan, masukan dan berbagi pengalaman kepada penulis dalam berproses untuk mengekprolasi tentang dunia pendidikan anak usia dini di perguruan tinggi.

\section{DAFTAR PUSTAKA}

Aloia, L. S., \& Warren, R. (2019). Quality Parent-Child Relationships: The Role of Parenting Style and Online Relational Maintenance Behaviors. Communication Reports, 32(2), 43-56. https://doi.org/10.1080/08934215.2019.1582682

Ardita Ceka, R. M. (2016). the Role of the Parents in the Education of Children. Journal of Education and Practice, 7(5), 61-64. https://doi.org/10.1111/j.14401819.1952.tb01331.x

Astuti, S., Adi, S., \& Puspita Ratih, S. (2021). Parenting with Unintended Pregnancy in East Java, Indonesia: A Qualitative Study. KnE Life Sciences, 2021(ISMoPHS 2020), 400411. https:// doi.org/10.18502/kls.v0i0.8899

Coyne, S. M., Radesky, J., Collier, K. M., Gentile, D. A., Linder, J. R., Nathanson, A. I., Rasmussen, E. E., Reich, S. M., \& Rogers, J. (2017). Parenting and digital media. Pediatrics, 140(November), S112-S116. https://doi.org/10.1542/peds.2016-1758N

Elam, K. K., Chassin, L., Eisenberg, N., \& Spinrad, T. L. (2017). Marital stress and children's externalizing behavior as predictors of mothers' and fathers' parenting. Development and Psychopathology, 29(4), 1305-1318. https:// doi.org/10.1017/S0954579416001322

Febriani, F., Asiyah, \& Syarifin, A. (2020). Pengaruh Pernikahan Dini Terhadap Pola Asuh Anak Dalam Keluarga. Journal Of Early Childhood Islamic Education, 4(1), 18-26. https:/ / doi.org/http://dx.doi.org/10.29300/alfitrah.v4i1.3796

Finigan-Carr, N. M., Murray, K. W., O'Connor, J. M., Rushovich, B. R., Dixon, D. A., \& Barth, R. P. (2015). Preventing rapid repeat pregnancy and promoting positive parenting among young mothers in foster care. Social Work in Public Health, 30(1), 1-17. https://doi.org/10.1080/19371918.2014.938388

Fono, Y. M., Fridani, L., \& Meilani, S. M. (2019). Kemandirian dan Kedisplinan Anak yang Diasuh oleh Orangtua Pengganti. Jurnal Obsesi: Jurnal Pendidikan Anak Usia Dini, 3(2), 537. https:/ / doi.org/10.31004/obsesi.v3i2.245

Gouveia, M. J., Carona, C., Canavarro, M. C., \& Moreira, H. (2016). Self-Compassion and Dispositional Mindfulness Are Associated with Parenting Styles and Parenting Stress: the Mediating Role of Mindful Parenting. Mindfulness, 7(3), 700-712. https://doi.org/10.1007/s12671-016-0507-y 
Handayani, R., Purbasari, I., \& Setiawan, D. (2020). Tipe-Tipe Pola Asuh Dalam Pendidikan Keluarga. Refleksi Edukatika : Jurnal Ilmiah Kependidikan, 11(1), 1623. https:// doi.org/10.24176/re.v11i1.4223

Hidayah, N., Tarnoto, N., \& Maharani, E. A. (2019). Profil Kebutuhan Pengasuhan Anak pada Pasangan Muda. Jurnal Ilmu Perilaku, 2(2), 89. https:/ / doi.org/10.25077/jip.2.2.89-106.2018

Hirata, H., \& Kamakura, T. (2018). The effects of parenting styles on each personal growth initiative and self-esteem among Japanese university students. International Journal of Adolescence and Youth, 23(3), 325-333. https:// doi.org/10.1080/02673843.2017.1371614

Ingersoll-Dayton, B., Tangchonlatip, K., \& Punpuing, S. (2020). A confluence of worries: Grandparents in skipped-generation households in Thailand. Journal of Family Issues, 41(2), 135-157. https:/ / doi.org/10.1177/0192513X19868836

Irwanto, Ikhtiar, I., Adi, A. C., \& Putri, A. O. (2019). Parenting Style in Early Marriage Mothers in Indonesia. Indonesian Journal of Medicine, 4(4), 313-320. https:// doi.org/10.26911/theijmed.2019.04.04.03

Latifiani, D. (2019). The Darkest Phase For Family: Child Marriage Prevention and Its Complexity In Indonesia. 4(2). https:/ / doi.org/DOI:10.15294/jils.v4i2.34708

Lestari, S. (2016). Psikologi Keluarga: Penanaman Nilai dan Penanganan Konflik dalam Keluarga. Prenadamedia Group.

Li, X., \& Xie, J. (2017). Parenting styles of Chinese families and children ' s social-emotional $\begin{array}{lll}\text { and cognitive developmental } & 1807 .\end{array}$ https://doi.org/10.1080/1350293X.2017.1331077

Mehrinejad, S. A., Rajabimoghadam, S., \& Tarsafi, M. (2015). The Relationship between Parenting Styles and Creativity and the Predictability of Creativity by Parenting Styles. Procedia - Social and Behavioral Sciences, 205(May), 56-60. https://doi.org/10.1016/j.sbspro.2015.09.014

Miles, M. B., \& Huberman, A. M. J. S. (2014). Qualitative Data Analysis. Sage Publications. Moleong, L. J. (2017). Metodologi Penelitian Kualitatif. PT Remaja Rosdakarya.

Nasution, N. A. D., Yumarni, V., \& Marwah, S. (2021). Tumbuh Kembang Anak dan Pola Pengasuhan Orang Tua pada Masa Golden Age di Ra Vinnaja Kabupaten Muaro Jambi Provinsi Jambi. Indonesian Journal of Early Childhood Islamic Education, $5(1)$,

27-38. https:// doi.org/10.35896/ijecie.v5i1.183

Nemet, M. B., \& Vrdoljak, G. (2021). Parenting Style and the Active Involvement of Fathers in Child-Rearing. 12(23), 107-125. https:// doi.org/10.21860/j.12.1.6

Nurdin, I., \& Hartati, S. (2019). Metodologi Penelitian Sosial. Media Sahabat Cendikia.

Purwadi, P. (2012). Perbedaan gaya pengasuhan orang tua desa dan kota. Proceeding Temu Ilmiah Nasional VIII IPPI, 239-250.

Rofingah, S. (2020). Metode Pengasuhan Anak Pasangan Pernikahan Dini (Studi Kasus Tiga Keluarga Pernikahan Dini Di Kecamatan Ponjong Kabupaten Gunungkidul Daerah Istimewa Yogyakarta). Hisbah: Jurnal Bimbingan Konseling Dan Dakwah Islam, 16(2), 166-179. https://doi.org/10.14421/hisbah.2019.162-05

Sahithya, B. R., Manohari, S. M., \& Vijaya, R. (2019). Parenting styles and its impact on children a cross cultural review with a focus on India. 4676. https:// doi.org/10.1080/13674676.2019.1594178

Sari, O., Winarni, S., \& Dharminto. (2018). Hubungan Adat Setempat, Pola Asuh, dan Persepsi Orang Tua dengan Umur Menikah Wanita PUS pada Pernikahan Dini di Kecamatan Karangrayung, Kabupaten Grobogan Tahun 2016. Jurnal Kesehatan Masyarakat, 6, 148-156. 
Sugiyono. (2015). Metode Penelitian Pendidikan (Pendekatan Kuantitatif, Kualitatif dan R\&D). Alfabeta.

Tridhonanto, A. (2014). Mengembangkan Pola Asuh Demokratis. Gramedia.

Ulya, N., Diana, R. R., Uin, P., Kalijaga, S., Uin, P., \& Kalijaga, S. (2021). Peran Pola Asuh Orang Tua Dalam Meningkatkan Kepercayaan Diri Pada Anak Usia. Jurnal Golden Age, 5(02), 304-313.

Vafaeenejad, Z., Elyasi, F., Moosazadeh, M., \& Shahhosseini, Z. (2020). Investigating the Predictive Role of Personality Traits on Parenting Styles in Couples of 6-12 Years Children. European Journal of Environment and Public Health., 4(2), 1-5. https:// doi.org/10.29333/ejeph/8215

Wiswanti, I. U., Kuntoro, I. A., Rizqi, N. P. A., \& Halim, L. (2020). Pola asuh dan budaya: Studi komparatif antara masyarakat urban dan masyarakat rural Indonesia. Jurnal Psikologi Sosial, 18(3), 211-223. https:// doi.org/10.7454/jps.2020.21

Zain, S. S., \& Fauziddin, M. (2020). Pendidikan Anak Usia Dini Pada Keluarga Muda di Desa Sumber Makmur Kecamatan Tapung. Journal On Teacher Education, 2, 270 289.

https://doi.org/10.31004/jote.v2i1.1244

Zakaria, M. R. A. (2019). Pengalihan peran sementara pengasuhan anak dari orang tua ke nenek dan kakek Temporary role for children caring from parents to grandmother and grandfather. Dialetika, 120-125. https://doi.org/10.20473/jsd.v14i2.2019.120-125 